Article

\title{
Biocompatible Electrochemical Sensor Based on Platinum-Nickel Alloy Nanoparticles for In Situ Monitoring of Hydrogen Sulfide in Breast Cancer Cells
}

\author{
Asit Kumar Panda ${ }^{1}$, Murugan Keerthi ${ }^{1}$, Rajalakshmi Sakthivel ${ }^{1}$, Udesh Dhawan ${ }^{2} \mathbb{D}$, Xinke Liu $^{3, *}$ \\ and Ren-Jei Chung $1, * \mathbb{D}$
}

check for

updates

Citation: Panda, A.K.; Keerthi, M.; Sakthivel, R.; Dhawan, U.; Liu, X.; Chung, R.-J. Biocompatible Electrochemical Sensor Based on Platinum-Nickel Alloy Nanoparticles for In Situ Monitoring of Hydrogen Sulfide in Breast Cancer Cells. Nanomaterials 2022, 12, 258. https:// doi.org/10.3390/nano12020258

Academic Editor: Camelia Bala

Received: 1 December 2021

Accepted: 10 January 2022

Published: 14 January 2022

Publisher's Note: MDPI stays neutral with regard to jurisdictional claims in published maps and institutional affiliations.

Copyright: (C) 2022 by the authors. Licensee MDPI, Basel, Switzerland. This article is an open access article distributed under the terms and conditions of the Creative Commons Attribution (CC BY) license (https:// creativecommons.org/licenses/by/ $4.0 /)$.
1 Department of Chemical Engineering and Biotechnology, National Taipei University of Technology (Taipei Tech), Taipei 10608, Taiwan; asitpanda6@gmail.com (A.K.P.); keerthimurugan1992@gmail.com (M.K.); rajalakshmicnr@gmail.com (R.S.)

2 Centre for the Cellular Microenvironment, University of Glasgow, Glasgow G12 8QQ, UK; Udesh.dhawan@glasgow.ac.uk

3 College of Materials Science and Engineering, Shenzhen University, Shenzhen 518060, China

* Correspondence: xkliu@szu.edu.cn (X.L.); rjchung@ntut.edu.tw (R.-J.C.); Tel.: +886-2-8772-8701 or +886-2-2771-2171 (ext. 2547) (R.-J.C.); Fax: +886-2-2731-7117 (R.-J.C.)

\begin{abstract}
Hydrogen sulfide $\left(\mathrm{H}_{2} \mathrm{~S}\right)$, an endogenous gasotransmitter, is produced in mammalian systems and is closely associated with pathological and physiological functions. Nevertheless, the complete conversion of $\mathrm{H}_{2} \mathrm{~S}$ is still unpredictable owing to the limited number of sensors for accurate and quantitative detection of $\mathrm{H}_{2} \mathrm{~S}$ in biological samples. In this study, we constructed a disposable electrochemical sensor based on PtNi alloy nanoparticles (PtNi NPs) for sensitive and specific in situ monitoring of $\mathrm{H}_{2} \mathrm{~S}$ released by human breast cancer cells. PtNi alloy NPs with an average size of $5.6 \mathrm{~nm}$ were prepared by a simple hydrothermal approach. The conversion of different forms of sulfides (e.g., $\mathrm{H}_{2} \mathrm{~S}, \mathrm{HS}^{-}$, and $\mathrm{S}^{2-}$ ) under various physiological conditions hindered the direct detection of $\mathrm{H}_{2} \mathrm{~S}$ in live cells. PtNi NPs catalyze the electrochemical oxidation of $\mathrm{H}_{2} \mathrm{~S}$ in a neutral phosphate buffer ( $\mathrm{PB}, \mathrm{pH}$ 7.0). The PtNi-based sensing platform demonstrated a linear detection range of $0.013-1031 \mu \mathrm{M}$ and the limit of detection was $0.004 \mu \mathrm{M}(\mathrm{S} / \mathrm{N}=3)$. Moreover, the PtNi sensor exhibited a sensitivity of $0.323 \mu \mathrm{A} \mu \mathrm{M}^{-1} \mathrm{~cm}^{-2}$. In addition, the stability, repeatability, reproducibility, and anti-interference ability of the PtNi sensor exhibited satisfactory results. The PtNi sensor was able to successfully quantify $\mathrm{H}_{2} \mathrm{~S}$ in pond water, urine, and saliva samples. Finally, the biocompatible $\mathrm{PtNi}$ electrode was effectively employed for the real-time quantification of $\mathrm{H}_{2} \mathrm{~S}$ released from breast cancer cells and mouse fibroblasts.
\end{abstract}

Keywords: hydrogen sulfide; endogenous gasotransmitter; PtNi alloy; live cells; electrochemical sensor

\section{Introduction}

Hydrogen sulfide $\left(\mathrm{H}_{2} \mathrm{~S}\right)$ is the third most important endogenous gasotransmitter, followed by carbon monoxide (CO) and nitric oxide (NO) [1]. It is produced at a very low concentration in mammalian systems, mainly via a cysteine biosynthesis pathway by several enzymatic reactions to control several pathological activities such as cell proliferation, neurotransmission, antioxidation, and vascular inflammation [2]. $\mathrm{H}_{2} \mathrm{~S}$ also plays other essential biological roles, including anti-inflammation, angiogenesis, inhibition of insulin signaling, and regulation of blood pressure [3]. However, the accumulation of $\mathrm{H}_{2} \mathrm{~S}$ in the cellular environment is highly harmful to living organisms and can be related to several persistent diseases, such as Alzheimer's disease, fatal kidney disease, diabetes, Parkinson's disease, Down Syndrome, and even cancer [4]. Moreover, concentration imbalance of $\mathrm{H}_{2} \mathrm{~S}$ in living organisms damages the neurotransmission, immune response, blood pressure regulation, endocrine, gastrointestinal, and circulatory systems [5,6]. Due to its involvement in a large number of physiological processes, it is essential to develop fast, sensitive, 
and convenient methods to monitor endogenous $\mathrm{H}_{2} \mathrm{~S}$ in biological systems [7]. To date, various analytical methods for $\mathrm{H}_{2} \mathrm{~S}$ detection have been developed, including fluorimetry, spectrophotometry, chromatography, and chemiluminescence [8-10]. Chemiluminescence spectroscopy is often limited to use in biological samples because of its high temperature, long recovery time, and slow response [11]. Fluorescence, instead of imaging $\mathrm{H}_{2} \mathrm{~S}$ in live cells, is still unable to monitor real-time in situ fluctuations of $\mathrm{H}_{2} \mathrm{~S}$ [12]. Electrochemical biosensors are more convenient for in situ real-time monitoring of $\mathrm{H}_{2} \mathrm{~S}$ because of their high sensitivity, strong selectivity, rapidity, excellent reproducibility, ease of operation, and label-free detection $[13,14]$. However, the detection limit of $\mathrm{H}_{2} \mathrm{~S}$ sensors still needs to be improved owing to the low concentration of $\mathrm{H}_{2} \mathrm{~S}$ in the cells.

Recently, alloy NPs have gained considerable attention for various electrochemical applications. The noble metal platinum (Pt) is a commonly used electrocatalyst because of its superior catalytic activity $[15,16]$. Nevertheless, the catalytic performance of Pt nanoparticles can be hindered due to their tendency to self-aggregate [17]. Therefore, the alloying method has become a smart strategy for improving the electrochemical performance of Pt-based electrocatalysts, in which another metal is combined with Pt to form a Pt-M alloy $(\mathrm{M}=\mathrm{Ag}, \mathrm{Au}, \mathrm{Pd}, \mathrm{Ru}$, and $\mathrm{Ni})$, thus effectively modifying the electronic structure of $\mathrm{Pt}$ and its active surface sites $[18,19]$. Nickel (Ni) has been extensively applied in batteries, electroplating, and other applications owing to its high thermal resistance and excellent corrosion resistance. Nickel is also inexpensive and has high catalytic activity. PtNi bimetallic alloy NPs exhibit promising catalytic activity compared to pure Pt $[19,20]$. Alloying of $\mathrm{Pt}$ with Ni not only improves the catalytic activity but also decreases the cost of the material. Moreover, with the incorporation of $\mathrm{Ni}$, the lattice of Pt shrinks, and the distance between adjacent Pt-Pt decreases. The decrease in the distance between adjacent Pt atoms facilitates the reaction rate, specific activity and thus improves the electrochemical performance.

In this study, as shown in Scheme 1, PtNi alloy NPs were prepared by a hydrothermal method, and a modified PtNi electrode was employed for the detection of $\mathrm{H}_{2} \mathrm{~S}$. The crystalline structure, morphology, and elemental composition of the PtNi alloy NPs were determined using various characterization techniques. The electrocatalytic performance of the PtNi-modified electrode for the electrochemical detection of $\mathrm{H}_{2} \mathrm{~S}$ was investigated using voltammetry. PtNi alloy NPs have higher specific surface area thereby increasing the catalytic active sites and stability of the SPE for the efficient detection of $\mathrm{H}_{2} \mathrm{~S}$. Moreover, the sensitivity and selectivity of the PtNi-modified electrodes were studied using an amperometric (i-t) method. Finally, the PtNi sensor was employed for the practical analysis of $\mathrm{H}_{2} \mathrm{~S}$ in real samples, such as pond water, urine, and saliva samples.

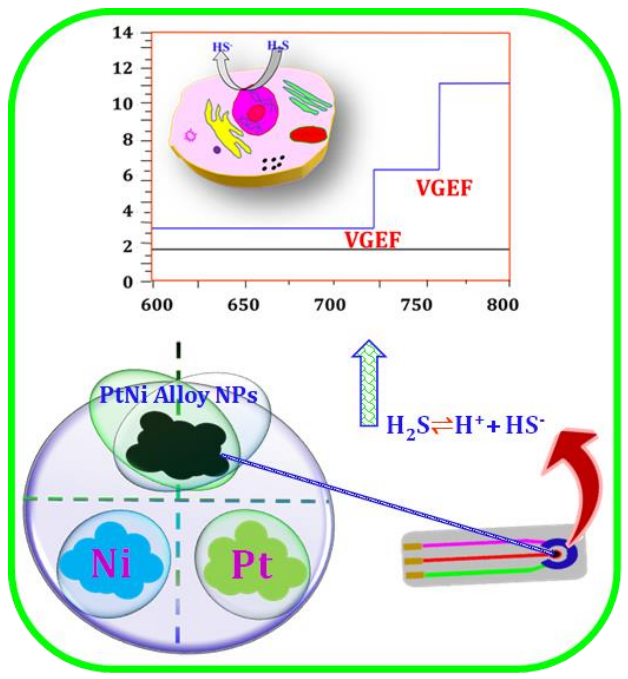

Scheme 1. Schematic representation of PtNi alloy NP formation and electrochemical detection of $\mathrm{H}_{2} \mathrm{~S}$ in a human breast cancer cell. 


\section{Materials and Methods}

\subsection{Chemicals and Reagents}

Platinum(II) acetylacetonate (Pt(acac) $2, \geq 97 \%)$, nickel(II) nitrate hexahydrate $\left(\mathrm{Ni}_{2}\left(\mathrm{NO}_{3}\right)_{2}\right.$. $\left.6 \mathrm{H}_{2} \mathrm{O}, \geq 99.9\right)$, ascorbic acid $\left(\mathrm{AA}, \mathrm{C}_{6} \mathrm{H}_{8} \mathrm{O}_{6}, \geq 99.1 \%\right)$, polyvinylpyrrolidone $\left(\mathrm{PVP},\left(\mathrm{C}_{6} \mathrm{H}_{9} \mathrm{NO}\right)_{\mathrm{n}}\right)$, sodium sulfide $\left(\mathrm{Na}_{2} \mathrm{~S}, \geq 99.0 \%\right)$, and all other chemicals were purchased from SigmaAldrich (St. Louis, MO, USA). Sodium phosphate monobasic $\left(\mathrm{NaH}_{2} \mathrm{PO}_{4}\right)$ and sodium phosphate dibasic $\left(\mathrm{Na}_{2} \mathrm{HPO}_{4}\right)$ were used for the preparation of $0.05 \mathrm{M}$ phosphate buffer (PB). Hydrochloric acid ( $\mathrm{HCl}, 36.5-38.0 \%)$ and sodium hydroxide $(\mathrm{NaOH}, \geq 98.0 \%)$ were used to adjust the $\mathrm{pH}$ of the PB. Double distilled (DD) water and ethanol were used for washing and other experiments. Three-pole screen-printed electrodes (SPEs) were purchased from Zensor (Taipei, Taiwan) (model TE-100).

\subsection{Instrumentation}

The morphology of the nanoparticles was observed using transmission electron microscopy (TEM) (TEM/JEM 2100 F; JEOL Ltd., Tokyo, Japan). The elemental weight percentages of the resultant materials were analyzed using energy dispersive $X$-ray analysis (EDX). The crystalline structure was analyzed by X-ray powder diffraction (XRD, X'Pert3 Powder, PANalytical, Almelo, The Netherlands). The chemical bonding of the composites was analyzed by X-ray photoelectron spectroscopy (XPS). Electrochemical experiments were performed using a CH Instruments 6041E workstation (Austin, TX, USA). For the cyclic voltammetry (CV) experiments, the SPE was used as a working, reference, and counter electrode. Amperometry (i-t) experiments were carried out at an optimum potential of $0.49 \mathrm{~V}$ using a rotating disc electrode (RDE) as the working electrode, $\mathrm{Ag} / \mathrm{AgCl}$ as the reference electrode, and a Pt wire as the counter electrode.

\subsection{Synthesis of PtNi Alloy Nanoparticles}

PtNi alloy NPs were synthesized via a facile hydrothermal route using dimethylformamide (DMF) as the solvent. In this process, the nanoparticles were synthesized by dissolving the precursors $\mathrm{Pt}(\mathrm{acac})_{2}(100 \mathrm{mg})$ and $\mathrm{Ni}\left(\mathrm{NO}_{3}\right)_{2} \cdot 6 \mathrm{H}_{2} \mathrm{O}(100 \mathrm{mg})$ in $80 \mathrm{ml}$ of DMF, and the mixture was stirred continuously with a magnetic stirrer for $30 \mathrm{~min}$. Next, $0.5 \mathrm{~g}$ of ascorbic acid (AA) as a reducing agent and $0.8 \mathrm{~g}$ of PVP as a surfactant were added to the above mixture, which was stirred for another $30 \mathrm{~min}$. This mixture was hydrothermally treated at $200{ }^{\circ} \mathrm{C}$ for $24 \mathrm{~h}$. Next, the PtNi alloy nanoparticles were separated by centrifugation, washed multiple times with hexane and ethanol, and dried in an oven at $50{ }^{\circ} \mathrm{C}$ for $12 \mathrm{~h}$.

\subsection{Fabrication of PtNi-Modified Electrode}

The synthesized PtNi nanoparticles $\left(1 \mathrm{mg} \mathrm{mL}^{-1}\right)$ were dispersed in DD water via ultrasonic treatment for $20 \mathrm{~min}$ to obtain a uniform suspension. The optimized amount $(6.0 \mu \mathrm{L})$ of the PtNi suspension was coated on the SPE using a micropipette and then dried at $50{ }^{\circ} \mathrm{C}$ for $30 \mathrm{~min}$ to obtain PtNi/SPE. Bare SPE was used in control studies.

\subsection{Cell Culture}

Breast cancer cells (MDA-MB-231, ATCC, Manassas, VA, USA) and mouse fibroblasts (L929, ATCC, Manassas, VA, USA) were cultured in DMEM supplemented with 10\% fetal bovine serum (FBS) (Gibco, Amarillo, TX, USA), $100 \mathrm{U} \mathrm{mL}^{-1}$ penicillin, and $100 \mu \mathrm{g} \mathrm{mL}^{-1}$ streptomycin. Cells were seeded in T75 flasks in a $\mathrm{CO}_{2}$ incubator maintained at $37{ }^{\circ} \mathrm{C}$, $5 \% \mathrm{CO}_{2}$, and $95 \%$ humidity.

\subsection{Biocompatibility Analysis}

The in vitro cytotoxicity was assessed using the MTT assay. MTT reagent $\left(5 \mathrm{mg} \mathrm{mL}^{-1}\right)$ was prepared and stored at $4{ }^{\circ} \mathrm{C}$ in the dark. First, the stock solution was diluted to 10 -fold using a culture medium. MDA-MB-231 and L929 cells $\left(1 \times 10^{4}\right.$ per well $)$ were cultured in 96 well plates for $24 \mathrm{~h}$ to evaluate the in vitro cytotoxicity of the PtNi nanoparticles. After 
$24 \mathrm{~h}$ of incubation, the cells were washed twice with PBS. Next, $50 \mu \mathrm{L}$ of MTT reagent in $0.5 \mathrm{~mL}$ of culture medium was added to the cells and incubated for $4 \mathrm{~h}$ in the dark. MTT reagent was then removed from the culture medium, and formazan crystals were dissolved by adding $200 \mu \mathrm{L}$ of DMSO per well. The plates were shaken using a rotary shaker at $100 \mathrm{rpm}$ for $10 \mathrm{~min}$ at room temperature.

\subsection{Detection of $\mathrm{H}_{2} \mathrm{~S}$ in Live Cells}

MDA-MB-231 and L929 cells were cultured in T75 flasks for $24 \mathrm{~h}$ and grown in DMEM. The cell culture medium was removed after $90 \%$ confluence of cells; the cells were then washed thrice with PB and collected by centrifugation. The number of cells was counted using a hemocytometer. Cells $\left(2 \times 10^{7}\right)$ were dispersed in $80 \mathrm{~mL}$ of PB ( $\left.\mathrm{pH} 7.0\right)$, and vascular endothelial growth factor (VEGF) was used as a stimulator to stimulate $\mathrm{H}_{2} \mathrm{~S}$ production. Then, amperometry experiments in live cells were performed at a fixed potential of $0.49 \mathrm{~V}$ and VEGF was injected into the PB without cells as a control sample.

\section{Results}

X-ray diffraction (XRD) was employed to examine the crystalline structure of PtNi NPs (Figure 1a). The PtNi shows peaks at $40.2^{\circ}, 48.2^{\circ}, 68.3^{\circ}$, and $83.7^{\circ}$ corresponding to the (111), (200), (220), and (311) planes, respectively, indicating a face-centered cubic (fcc) structure (JCPDS 65-9445). This indicates the formation of a pure PtNi alloy without any other impurities such as $\mathrm{Ni}$ oxide and Pt oxide [19]. In addition, all the diffraction peaks of PtNi NPs were broadened compared to those for Pt, indicating the small size of the nanocrystals of PtNi alloy because Ni diffused into the crystal lattice of Pt, leading to lattice compression.
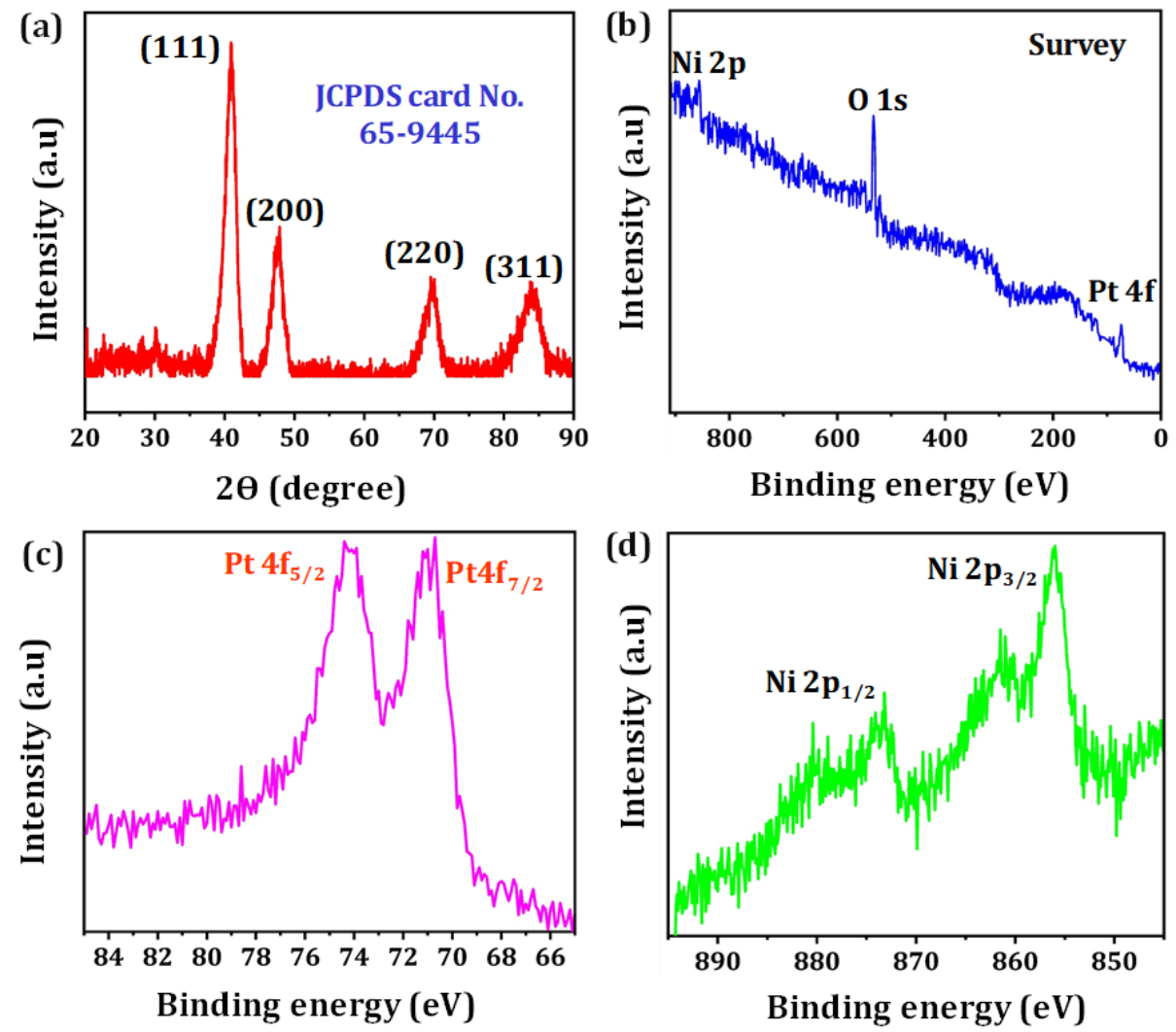

Figure 1. (a) XRD pattern of PtNi NPs, (b) survey spectrum of PtNi NPs, magnified XPS profiles of (c) Pt $4 \mathrm{f}$ and (d) Ni 2p.

XPS was employed to study the elemental states and composition of the PtNi NPs. The overall survey of the PtNi alloys in Figure $1 \mathrm{~b}$ confirms the presence of the individual 
elements Pt and Ni. Additionally, an intense peak is observed at approximately $530 \mathrm{eV}$ in the survey spectrum due to the presence of atmospheric oxygen atoms. Figure 1c shows a magnified spectrum of $\mathrm{Pt} 4 \mathrm{f}$, with two peaks located at $74.3 \mathrm{eV}$ and $70.6 \mathrm{eV}$ indexed to $\mathrm{Pt}$ $4 \mathrm{f}_{5 / 2}$ and $\mathrm{Pt} 4 \mathrm{f}_{7 / 2}$ of the PtNi nanoalloy, indicating $\mathrm{Pt}$ in the metallic $\mathrm{Pt}^{0}$ state. Figure $1 \mathrm{~d}$ shows two peaks at $852.7 \mathrm{eV}$ and $870.6 \mathrm{eV}$ ascribed to $\mathrm{Ni} 2 \mathrm{p}_{3 / 2}$ and $\mathrm{Ni} 2 \mathrm{p}_{1 / 2}$, respectively, indicating the metallic $\mathrm{Ni}^{0}$ state [21]. These XPS results further confirm the formation of an alloy nanostructure.

The morphology and nanoparticle size of the PtNi alloy were examined via TEM measurements. The TEM image of the PtNi alloy (Figure 2a) shows identical spherical PtNi alloy NPs with an average diameter of $\sim 5-6 \mathrm{~nm}$, and Image J software was used to measure their size. Representative high-resolution TEM (HRTEM) images of the PtNi alloy are presented in Figure $2 b, c$, which exhibit clear and evenly spaced lattice fringes. The lattice spacing distances for the PtNi alloy are $0.198 \mathrm{~nm}$ and $0.224 \mathrm{~nm}$, which agrees with the (200) and (111) planes of the PtNi alloys. Figure 2d displays SAED patterns of PtNi nano alloys, which show clear circles ascribed to the (111), (200), (220), and (311) planes, consistent with the XRD results [22]. To further verify the size of the PtNi alloy particles, particle size distribution analysis was performed (Figure 1e), and the average particle size of PtNi NPs was calculated to be $5.6 \pm 1.4 \mathrm{~nm}$. The EDS mapping results of the PtNi NPs (Figure 2f) reveal that the Pt and Ni are evenly distributed throughout the particle. Moreover, the weight percentages of $\mathrm{Pt}$ and Ni were analyzed by EDX (Figure $2 \mathrm{~g}$ ) and found to be $77.56 \%$ and $22.44 \%$, respectively.

(a)

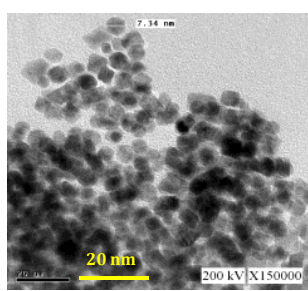

(d)
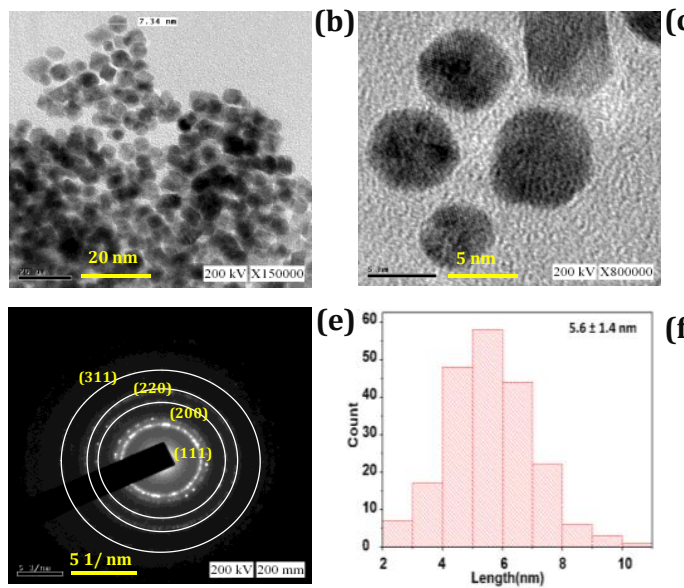

(g)

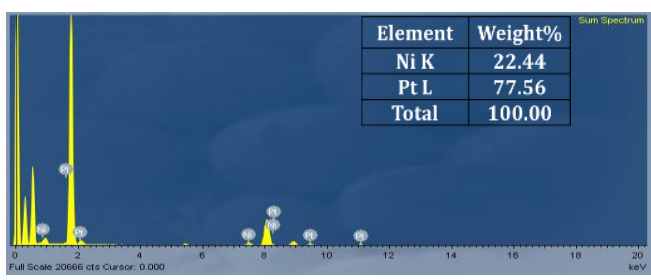

(c)

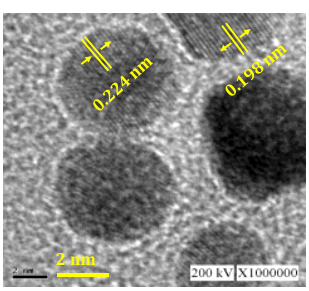

(f)
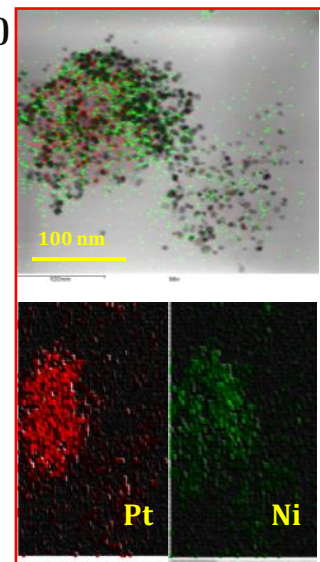

Figure 2. (a) TEM image, (b,c) HRTEM images, (d) selected area electron diffraction (SAED) pattern, (e) particle size distribution, (f) EDX mapping images, (g) EDX spectrum of PtNi NPs (insert: elemental weight percentage).

\subsection{Electrochemical Detection of $\mathrm{H}_{2} \mathrm{~S}$ at PtNi/SPE}

The electrocatalytic activity of bare SPE and PtNi/SPE towards the oxidation of $100 \mu \mathrm{M}$ of sulfide was estimated by $\mathrm{CV}$ in $0.05 \mathrm{M} \mathrm{PB}$ ( $\mathrm{pH} 7.0$ ) at a scan rate of $0.05 \mathrm{~V} \mathrm{~s}^{-1}$ (Figure 3a). In the aqueous solution $\mathrm{Na}_{2} \mathrm{~S}$ dissociated into $\mathrm{Na}^{+}, \mathrm{OH}^{-}$, and $\mathrm{H}_{2} \mathrm{~S}$. The bare $\mathrm{SPE}$ does not display any noticeable peak for $\mathrm{H}_{2} \mathrm{~S}$, indicating the absence of catalytic sites on the bare SPE surface. On the other hand, SPEs modified with PtNi enhance the peak intensities due to the oxidation of hydrogen sulfide $\left(\mathrm{H}_{2} \mathrm{~S}\right)$ into bisulfite ion $\left(\mathrm{HS}^{-}\right)$with the transfer of $2 \mathrm{e}^{-}$and $2 \mathrm{H}^{+}$. The higher specific surface area of the PtNi alloy forms a network structure 
on the surface of the electrode, which is beneficial to increase the catalytic performance of the sensing materials. The stability of PtNi/SPE for the detection of $100 \mu \mathrm{M}$ sulfide was investigated by repeatedly scanning the PtNi/SPE (50 cycles) (Figure 3b). After 50 cycles, the current response of PtNi/SPE towards sulfide was $85 \%$ of its initial (1st cycle) response, indicating outstanding electrochemical stability of the PtNi-modified electrode.
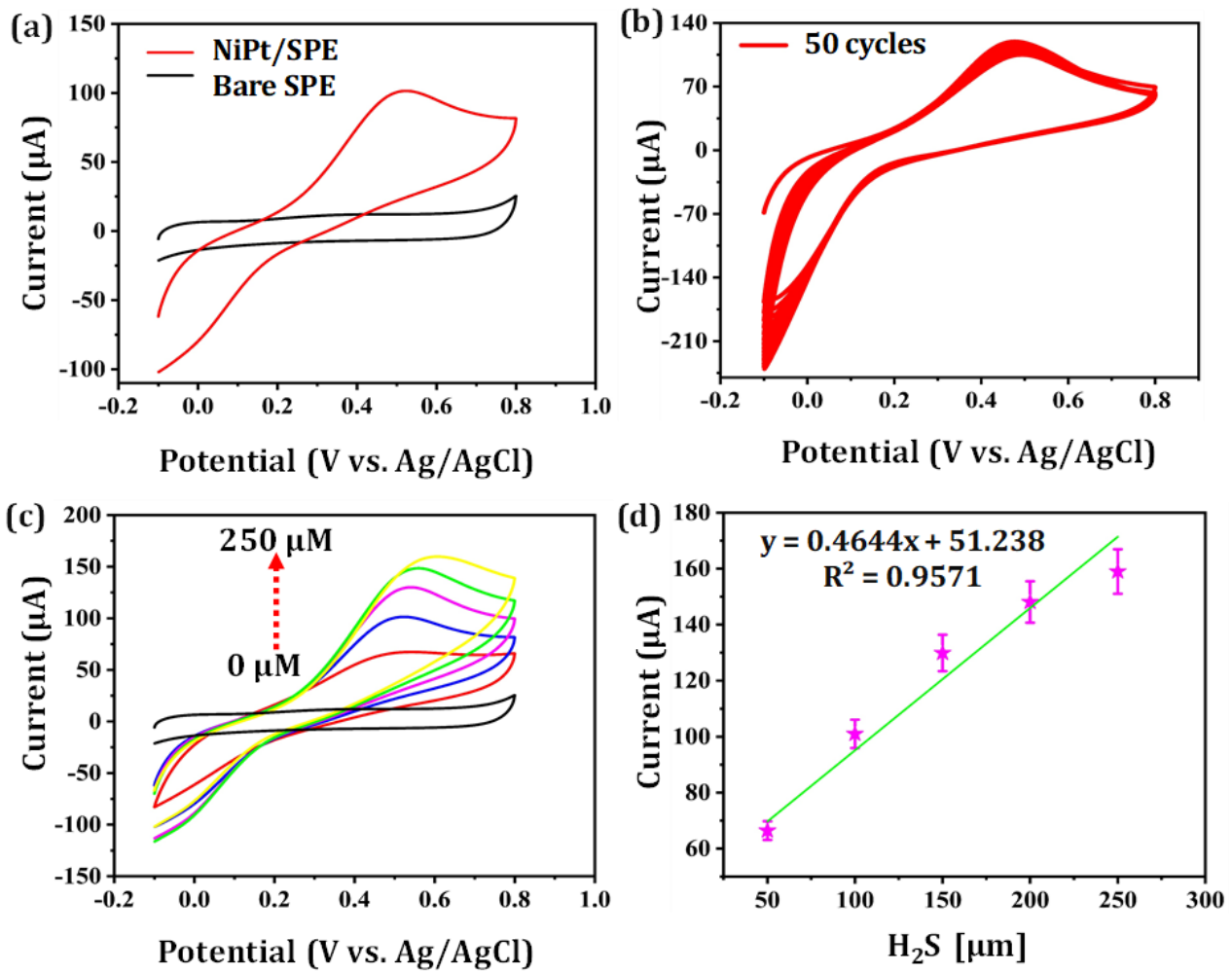

Figure 3. (a) CV curves of bare SPE and PtNi/SPE for $100 \mu \mathrm{M}$ sulfide in $0.05 \mathrm{M} \mathrm{PB}$ (pH 7.0) at a scan rate of $0.05 \mathrm{~V} \mathrm{~s}^{-1}$, (b) 50 consecutive CV cycles of PtNi/SPE in $0.05 \mathrm{M} \mathrm{PB} \mathrm{(pH} \mathrm{7.0)} \mathrm{containing} 100 \mu \mathrm{M}$ of sulfide at a scan rate of $0.05 \mathrm{~V} \mathrm{~s}^{-1}$, (c) CV curves of different concentrations of sulfide $(0-250 \mu \mathrm{M})$ at PtNi/SPE in 0.05 M PB (pH 7.0), (d) calibration plot of $\mathrm{I}_{\mathrm{pa}}$ vs. concentration $(\mu \mathrm{M})$ of sulfide.

The electrochemical sensitivity of $\mathrm{PtNi} / \mathrm{SPE}$ was studied at various sulfide concentrations. Figure $3 c$ presents CV curves of sulfide at different concentrations $(0-250 \mu \mathrm{M})$ on $\mathrm{PtNi} / \mathrm{SPE}$ in PB (pH 7.0). As the concentration of sulfide increases from 0 to $250 \mu \mathrm{M}$, the peak intensity of the oxidation peak of sulfide also gradually increases linearly. The obtained $\mathrm{I}_{\mathrm{pa}}$ versus sulfide concentration plot is displayed in Figure $3 \mathrm{~d}$. The linear regression and coefficient are as follows: $I_{p a}(\mu \mathrm{A})=0.464\left[\mathrm{H}_{2} \mathrm{~S}\right](\mu \mathrm{M})+51.238$ and $\mathrm{R}^{2}=0.957$, respectively.

Furthermore, $\mathrm{CV}$ was employed to investigate the influence of $\mathrm{pH}$ with $100 \mu \mathrm{M}$ sulfide at PtNi/SPE (Figure 4a). It can be seen that the $\mathrm{pH}$ of the $0.05 \mathrm{M}$ PB significantly influences the $\mathrm{H}_{2} \mathrm{~S}$ oxidation at the PtNi-modified electrode. Figure $4 \mathrm{~b}$ shows a plot of the oxidation current of sulfide at PtNi/SPE vs. $\mathrm{pH}$ (3.0-11.0). An enhancement in the $\mathrm{I}_{\mathrm{pa}}$ value was observed from $\mathrm{pH} 5.0$ to 11.0, and the highest $\mathrm{I}_{\mathrm{pa}}$ was obtained at $\mathrm{pH}$ 7.0. Therefore, $\mathrm{H}_{2} \mathrm{~S}$ detection is best performed at a $\mathrm{pH}$ of $7.0 . \mathrm{H}_{2} \mathrm{~S}$ is a weak acid with values of $\mathrm{pK}_{\mathrm{a} 1}$ and $\mathrm{pK}_{\mathrm{a} 2}$, as indicated in Equations (1) and (2):

$$
\begin{array}{cc}
\mathrm{H}_{2} \mathrm{~S} \rightleftharpoons \mathrm{HS}^{-} & \mathrm{pK}_{\mathrm{a} 1}=6.9 \\
\mathrm{HS} \rightleftharpoons \mathrm{S}^{2-} & \mathrm{pK}_{\mathrm{a} 2}=14.15
\end{array}
$$



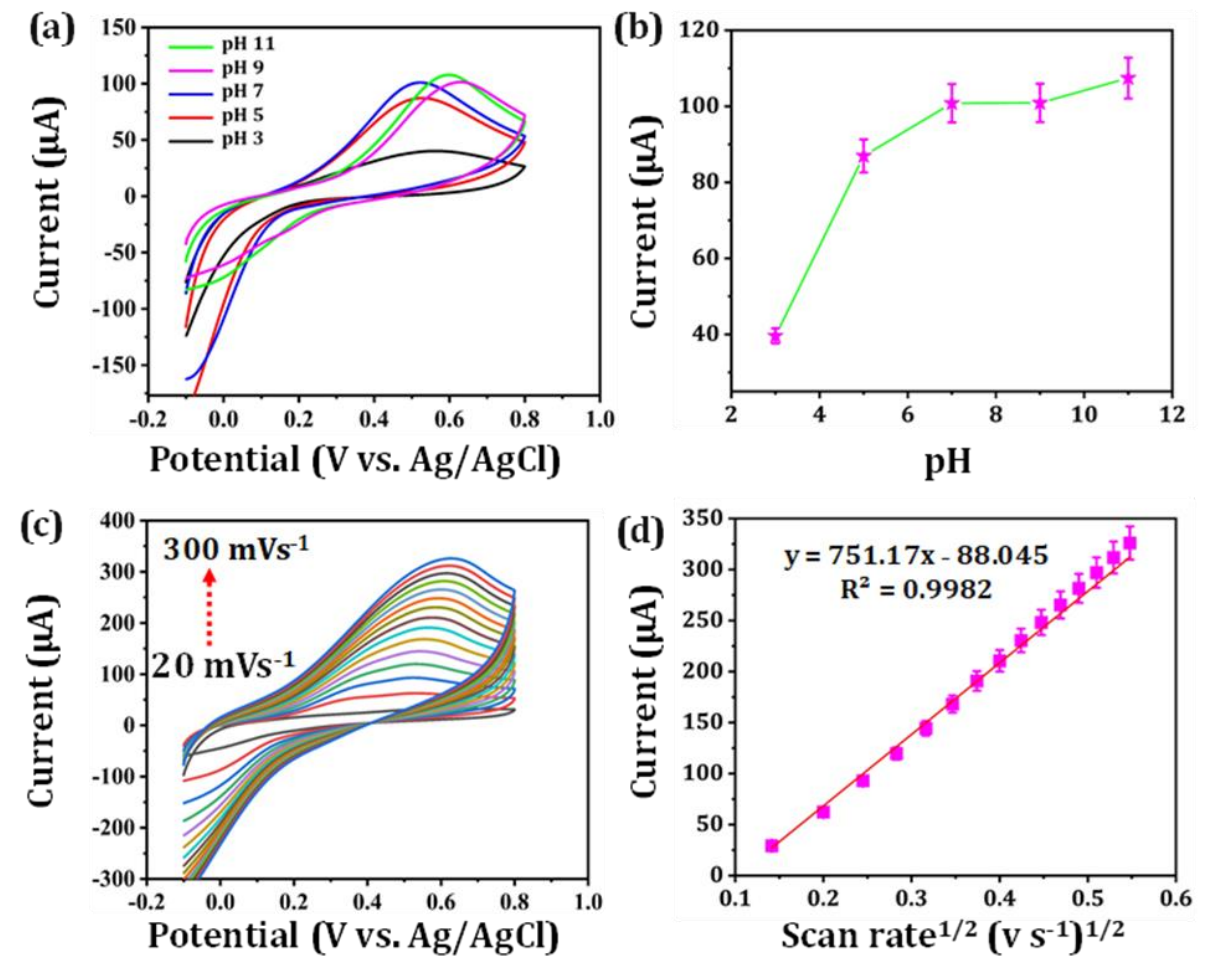

Figure 4. (a) CV curves of $100 \mu \mathrm{M}$ sulfide at the PtNi/SPE in $0.05 \mathrm{M}$ PB at pHs from 3.0 to 11.0 at a scan rate of $0.05 \mathrm{~V} \mathrm{~s}^{-1}$, (b) plot of $\mathrm{pH}$ vs. current response, (c) CV response of PtNi/SPE for $100 \mu \mathrm{M}$ of sulfide at various scan rates $\left(0.02-0.3 \mathrm{~V} \mathrm{~s}^{-1}\right),(\mathrm{d})$ linear plot of $\mathrm{I}_{\mathrm{pa}}$ of sulfide vs. square root of scan rate $\left(\mathrm{Vs}^{-1}\right)^{1 / 2}$.

At a neutral $\mathrm{pH}$ of 7.0 , sulfide is present as $20 \% \mathrm{H}_{2} \mathrm{~S}, 80 \% \mathrm{HS}^{-}$, and $0 \% \mathrm{~S}^{2-}$, whereas $\mathrm{H}_{2} \mathrm{~S}$ and $\mathrm{S}^{2-}$ are the prominent forms at strong acidic and basic $\mathrm{pHs}$, respectively [23]. Of the three forms of sulfide, the most electrochemically detectable form is $\mathrm{HS}^{-}$. Moreover, the $\mathrm{H}_{2} \mathrm{~S}$ oxidation rate in strong acid or strong base is sluggish because of the lower availability of the $\mathrm{HS}^{-}$form. Neutral PB with a $\mathrm{pH}$ of 7.0 is essential to create a suitable environment for the conversion of $\mathrm{H}_{2} \mathrm{~S}$ to $\mathrm{HS}^{-}$; therefore, $\mathrm{pH} 7.0$ was selected for further studies.

The electrokinetic behavior of PtNi/SPE was studied by $\mathrm{CV}$ at various scan rates (20-300 $\mathrm{mVs}^{-1}$ ) for $100 \mu \mathrm{M}$ sulfide (Figure $4 \mathrm{c}$ ). When the scan rate increases from 0.02 to $0.3 \mathrm{~V} \mathrm{~s}^{-1}$, the $\mathrm{I}_{\mathrm{pa}}$ of sulfide also increases linearly and the oxidation peak potential $\left(\mathrm{E}_{\mathrm{pa}}\right)$ is shifted towards the positive direction. A linear plot was obtained between the $\mathrm{I}_{\mathrm{pa}}$ of sulfide and the square root of the scan rate, with a linear regression equation $I_{p a}(\mu A)=751.17 \mathrm{v}^{1 / 2}$ $\left(\mathrm{Vs}^{-1}\right)^{1 / 2}-88.045$ and a regression coefficient $\mathrm{R}^{2}=0.9933$ (Figure $4 \mathrm{~d}$ ), indicating that the electrochemical oxidation of sulfide on PtNi/SPE is a diffusion-controlled process.

\subsection{Amperometric Determination of $\mathrm{H}_{2} \mathrm{~S}$ at PtNi/SPE}

Before determining the typical amperometric response for $\mathrm{H}_{2} \mathrm{~S}$, it is necessary to determine the optimum applied potential for efficient $\mathrm{H}_{2} \mathrm{~S}$ detection. Current-time (i-t) curves were recorded at different potentials $(0.49,0.69,0.72$, and $0.22 \mathrm{~V}$ vs. $\mathrm{Ag} / \mathrm{AgCl})$ with successive additions of sulfide $(0.625-41.2 \mu \mathrm{M})$. A higher and more stable $\mathrm{I}_{\text {pa }}$ with lower background noise was obtained at $0.49 \mathrm{~V}$ compared to that at other potentials (Figure 5a). A linear relationship was observed between $\mathrm{I}_{\mathrm{pa}}$ and $\left[\mathrm{H}_{2} \mathrm{~S}\right]$ over a wide range of potentials (Figure $5 b$ ). Therefore, a potential of $0.49 \mathrm{~V}$ was selected as the most suitable potential for the subsequent amperometric $\mathrm{H}_{2} \mathrm{~S}$ detection measurements. 

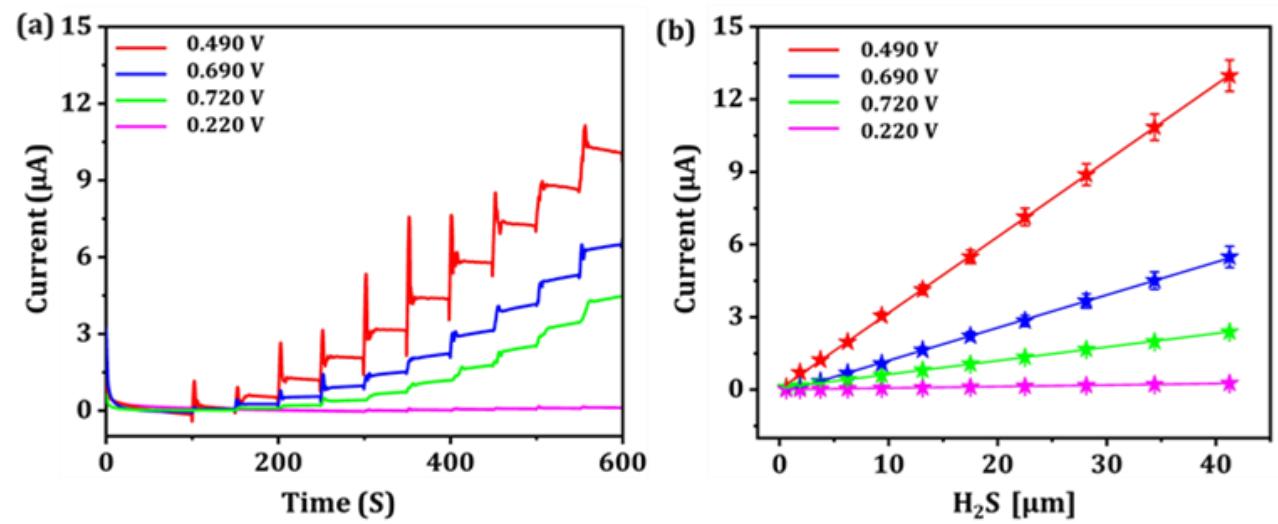

Figure 5. (a) Amperometry (i-t) response of the PtNi/SPE with different concentrations of sulfide $(0.625-41.2 \mu \mathrm{M})$ in $0.05 \mathrm{M} \mathrm{PB}(\mathrm{pH} 7.0)$ at various working potential ranges $(0.49,0.69,0.72$, and $0.22 \mathrm{~V})$, (b) corresponding linear plot of $\mathrm{I}_{\mathrm{pa}}$ vs. $\left[\mathrm{H}_{2} \mathrm{~S}\right]$ for different potentials.

After determining the optimum potential, the sensing performance of PtNi towards sulfide was investigated. Figure 6a illustrates the amperometric (i-t) response of PtNi with successive additions of various concentrations of sulfide into $0.05 \mathrm{M} \mathrm{PB} \mathrm{(pH} \mathrm{7.0)} \mathrm{at} \mathrm{regular}$ intervals of $50 \mathrm{~s}$ under stirring. As depicted in Figure $6 \mathrm{a}$, the $\mathrm{I}_{\mathrm{pa}}$ increased quickly with the successive additions of sulfide, and reached a steady-state current within $4.8 \mathrm{~s}$ after each addition (Figure 6b). This result demonstrates electrochemical activity and quick adsorption of $\mathrm{H}_{2} \mathrm{~S}$ molecules on the PtNi electrode surface. The corresponding amperometric current response versus sulfide concentration is shown in Figure 6c. A linear relationship was found for $\mathrm{PtNi}$ in the range $0.0125-1031 \mu \mathrm{M}$ with a linear regression equation $\mathrm{I}_{\mathrm{pa}}(\mu \mathrm{A})$ $=0.0679\left[\mathrm{H}_{2} \mathrm{~S}\right](\mu \mathrm{M})+0.732$ and a coefficient $\mathrm{R}^{2}=0.999$. Based on the limit of detection $(\mathrm{LOD})=3 \mathrm{~S} / \mathrm{k}$, the LOD was determined to be $0.004 \mu \mathrm{M}$, where ' $\mathrm{k}$ ' indicates the slope value $\left(0.0679 \mu \mathrm{A} \mu \mathrm{M}^{-1}\right)$ achieved from the linear plot, and ' $\mathrm{S}$ ' indicates the standard deviation from three blank measurements $(0.0001 \mu \mathrm{A})$. Moreover, the sensitivity of the PtNi sensor was calculated to be $0.323 \mu \mathrm{A} \mu \mathrm{M}^{-1} \mathrm{~cm}^{-2}$. The obtained linear range and LOD of our PtNi sensor were compared with those of previously reported $\mathrm{H}_{2} \mathrm{~S}$ sensors, as displayed in Table 1. In comparison, the analytical performance of the proposed PtNi sensor was superior to that of most of the other proposed $\mathrm{H}_{2} \mathrm{~S}$ detection methods.

An interference study was performed to investigate the selectivity of PtNi toward the oxidation of sulfide with other interfering compounds. The current response for the consecutive addition of sulfide and some potential interferences were investigated in PB ( $\mathrm{pH} 7.0$ ) at $0.49 \mathrm{~V}$ on a PtNi sensor (Figure 6d). A 10-fold excess concentration of $\mathrm{Na}^{+}, \mathrm{K}^{+}$, $\mathrm{CO}, \mathrm{NO}$, hydrogen peroxide $\left(\mathrm{H}_{2} \mathrm{O}_{2}\right)$, uric acid (UA), ascorbic acid (AA), L-cysteine (L-cys), dopamine (DA), and $\mathrm{Cl}^{-}$had no substantial influence on the amperometric response; however, the addition of sulfide resulted in a notable change in the amperometric response. These results suggest that the PtNi sensor has excellent selectivity towards $\mathrm{H}_{2} \mathrm{~S}$ oxidation and exhibits high anti-fouling by the interfering compounds. 

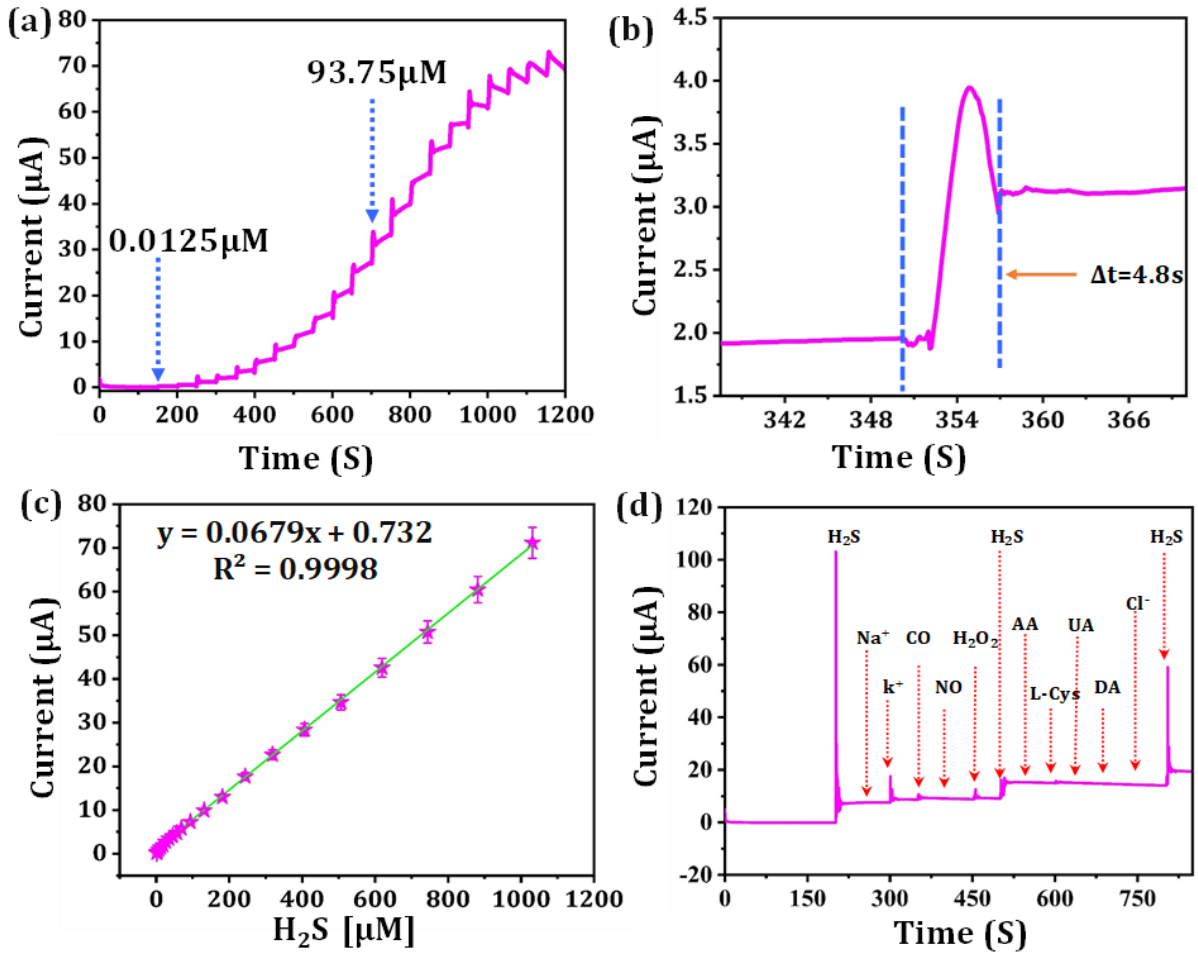

Figure 6. (a) Amperometry (i-t) response of various concentrations of sulfide $(0.0125-1031 \mu \mathrm{M})$ in $0.05 \mathrm{M}$ PB (pH 7.0), (b) response time for steady-state current, (c) corresponding linear plot for $\mathrm{I}_{\mathrm{pa}} \mathrm{vs}$. [sulfide] (d) effect of interfering species $\mathrm{Na}^{+}, \mathrm{K}^{+}, \mathrm{CO}, \mathrm{NO}$, hydrogen peroxide $\left(\mathrm{H}_{2} \mathrm{O}_{2}\right)$, ascorbic acid (AA), L-cysteine (L-cys), uric acid (UA), dopamine (DA), and $\mathrm{Cl}^{-}$on the amperometric responses of $\mathrm{PtNi} / \mathrm{SPE}$ for sulfide in $0.05 \mathrm{M} \mathrm{PB}(\mathrm{pH} 7.0)$.

Table 1. Comparison of sensor parameters (linear range and LOD) for the proposed PtNi sensor with previously reported $\mathrm{H}_{2} \mathrm{~S}$ sensors.

\begin{tabular}{|c|c|c|c|c|}
\hline Modified Electrodes & Type & Linear Range $(\mu \mathrm{M})$ & LOD $(\mu \mathrm{M})$ & Ref. \\
\hline $\mathrm{Cu}_{2} \mathrm{O}-\mathrm{CuO} @ \mathrm{AuNIs} \mathrm{ODH}$ & Amperometry & $1-11,780$ & 0.7 & [13] \\
\hline magnetic CNT/Co/MoS 2 & Amperometry & $0.25-13,327$ & 0.12 & [24] \\
\hline Escherichia coli/NPG & Cyclic voltammetry & $0.4-33,000$ & 0.026 & [25] \\
\hline $\mathrm{Ti}_{3} \mathrm{C}_{2} \mathrm{Tx}$ MXene & Amperometry & $0.1-300$ & 0.016 & [26] \\
\hline $\begin{array}{l}\text { Boron Doped Diamond Flow } \\
\text { Electrodes }\end{array}$ & $\begin{array}{l}\text { Flow injection } \\
\text { Amperometry }\end{array}$ & $0-51.2$ & $0.37 \pm 0.03$ & [10] \\
\hline $\begin{array}{l}\text { Electropolymerized } \\
\text { film-modified GCEs }\end{array}$ & Amperometry & $0-15$ & 0.1 & [1] \\
\hline $\mathrm{PtNi}$ & Amperometry & $0.0125-1031$ & 0.004 & Present work \\
\hline
\end{tabular}

\subsection{Repeatability and Reproducibility}

The repeatability and reproducibility of the PtNi-modified electrodes were investigated by CV in $0.05 \mathrm{M}$ PB (pH 7.0) containing $100 \mu \mathrm{M}$ sulfide. The repeatability of the single PtNi/SPE toward sulfide was studied by observing the current response over five independent $\mathrm{CV}$ measurements under the same experimental conditions (Figure 7a). A relative standard deviation (RSD) of $3.37 \%$ was estimated from the bar diagram of $\mathrm{I}_{\mathrm{pa}}$ and the number of measurements (Figure $7 \mathrm{~b}$ ). A series of five different PtNi/SPE electrodes were prepared to evaluate the reproducibility of the PtNi/SPE, and the $\mathrm{I}_{\text {pa }}$ of $100 \mu \mathrm{M}$ sulfide on each electrode was observed by CV (Figure 7c). As shown in the bar diagram (Figure 7d), small changes in the $\mathrm{I}_{\mathrm{pa}}$ value with an RSD of 3.89\% demonstrated the excellent reproducibility of the PtNi/SPE sensor. In order to investigate the long-term stability of the proposed sensor, the current response of the PtNi electrode was analyzed by $100 \mu \mathrm{M}$ of the $\mathrm{H}_{2} \mathrm{~S}$ at the single electrode for 15 days. The current responses were measured every 3 days intervals after the PtNi electrode was stored in the refrigerator at $4^{\circ} \mathrm{C}$ (Figure 7e). 
The PtNi electrode retained $93.7 \%$ of current from its first day and the RSD value was calculated to be $4.82 \%$; the obtained result revealed the excellent long-term stability of our proposed sensor.
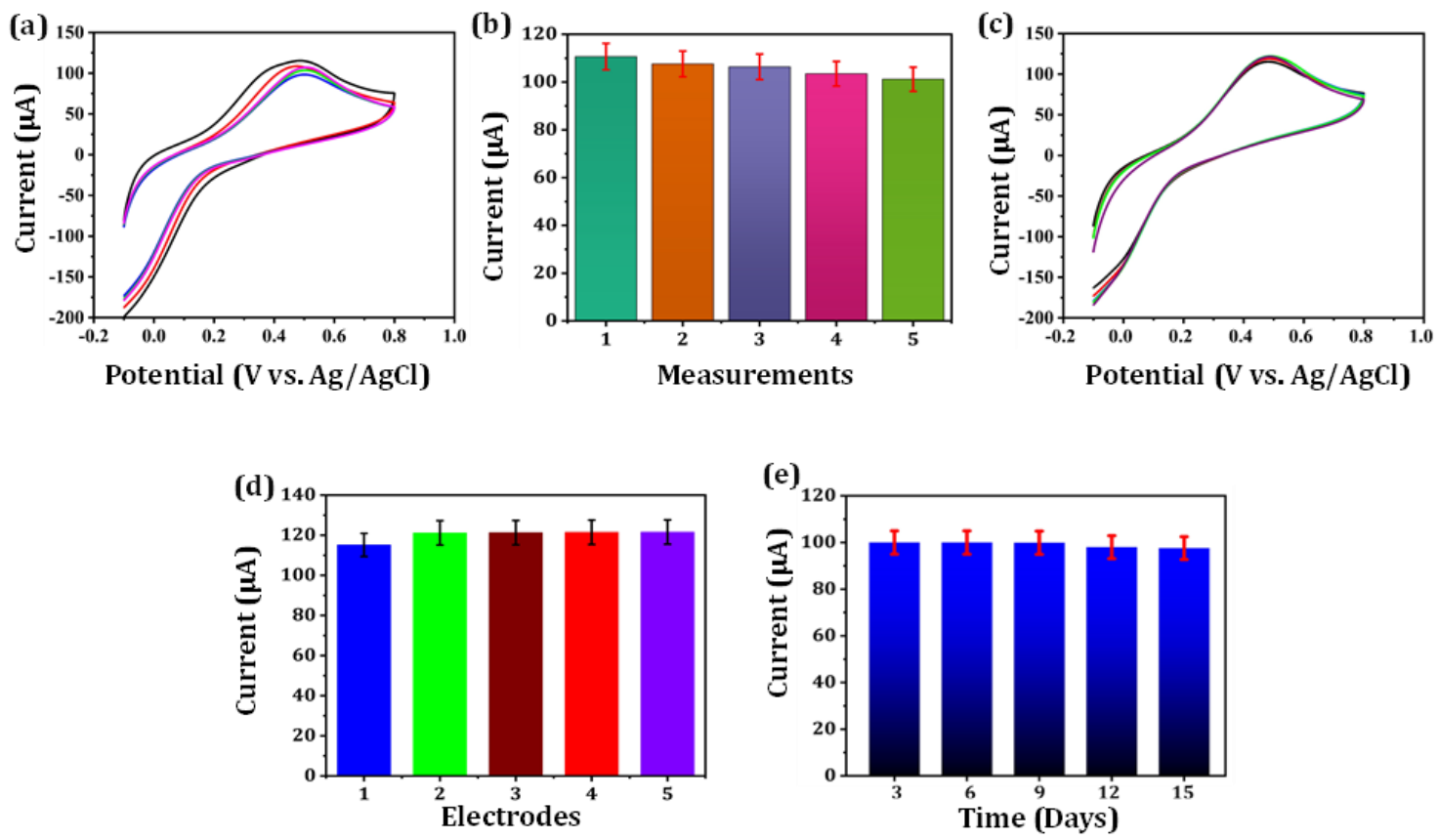

Figure 7. (a) Repeatability of the PtNi/SPE for 5 independent measurements in $0.05 \mathrm{M} \mathrm{PB}$ (pH-7.0) containing $100 \mu \mathrm{M}$ sulfide, (b) bar diagram of $\mathrm{I}_{\mathrm{pa}}$ and number of measurements, (c) Reproducibility of the PtNi/SPE, (d) bar diagram of $\mathrm{I}_{\mathrm{pa}}$ and number of PtNi/SPE, (e) stability bar diagram of PtNi/SPE over 15 days storage.

\subsection{Real Sample Analysis}

The practicality of the PtNi sensor was scrutinized by amperometric (i-t) measurements of sulfide in pond water, human urine, and saliva samples. The amperometric (i-t) response was recorded at $0.49 \mathrm{~V}$ in $0.05 \mathrm{M} \mathrm{PB}(\mathrm{pH} 7.0)$ with consecutive additions of real samples containing sulfide $(0.625-41.25 \mu \mathrm{M})$. A stock solution of pond water was diluted 10 times with $\mathrm{PB}$, a known concentration of $\mathrm{Na}_{2} \mathrm{~S}$ was injected into the stock solution, and the amperometric (i-t) response was observed for different consecutive additions of stock solution (0.625-41.25 $\mu \mathrm{M}$ ) in 0.05 M PB (pH 7.0) (Figure 8a). Similarly, collected human urine and saliva samples were separately diluted with $0.05 \mathrm{M} \mathrm{PB}$, and Whatman filter paper was used to filter them. Subsequently, a known concentration of sulfide was added to these real samples, and the amperometric (i-t) response was recorded using the standard addition method, as depicted in Figure 8c,e, respectively. Linear plots of $\mathrm{I}_{\mathrm{pa}} \mathrm{vs}$. [sulfide] for pond water, human urine, and human saliva samples are displayed in Figure $8 b, \mathrm{~d}, \mathrm{f}$. The recovery results are listed in Table 2 . The PtNi sensor exhibited good recovery values for all three real samples, with average recoveries of $92.4 \%, 95.6 \%$, and $98.8 \%$ for pond water, human urine, and human saliva samples, respectively. These results suggest that the PtNi sensor can be utilized as a reliable platform for the quantification of $\mathrm{H}_{2} \mathrm{~S}$ in real samples. 

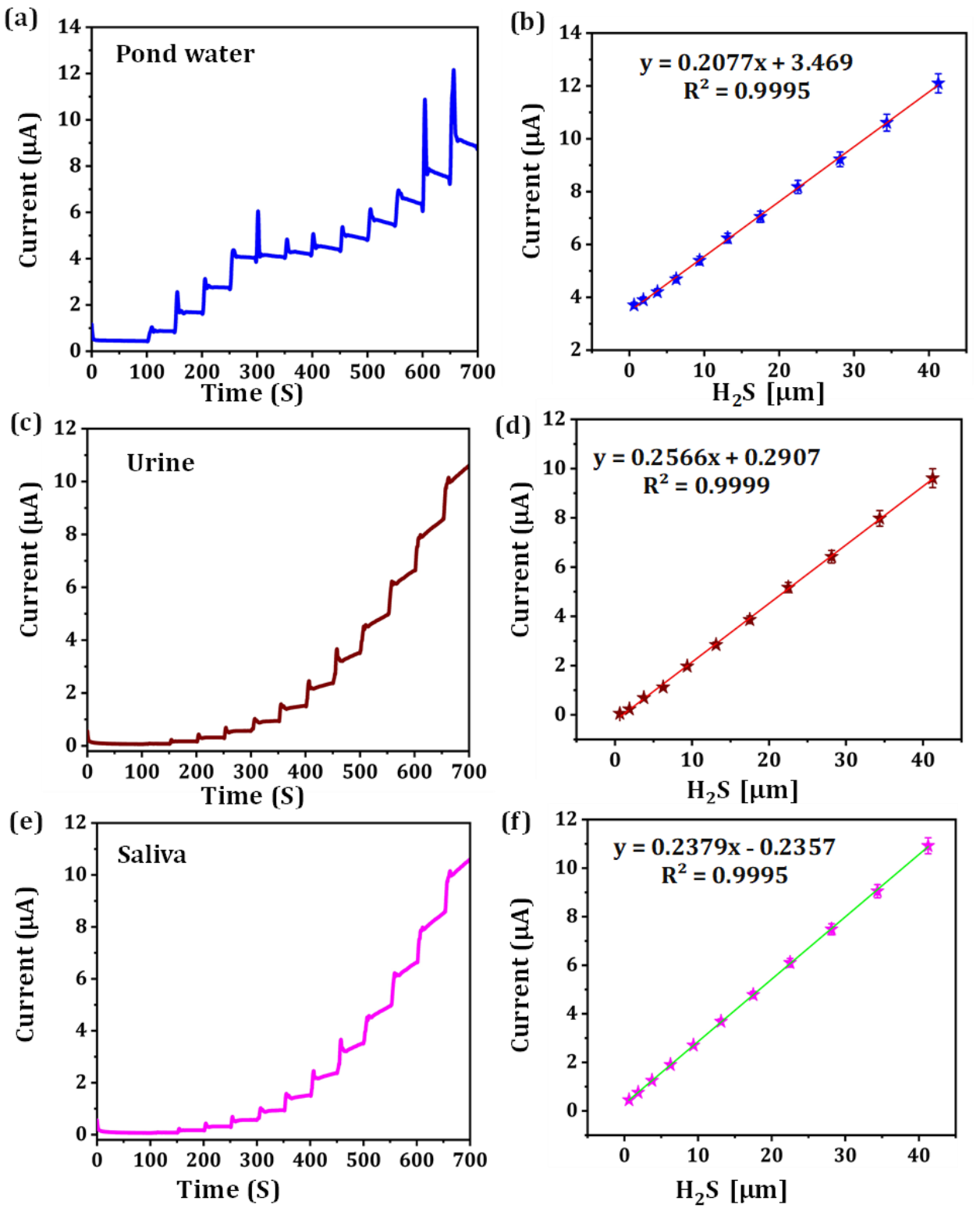

Figure 8. Detection of $\mathrm{H}_{2} \mathrm{~S}$ at PtNi-modified electrode in (a) pond water, (c) urine, and (e) saliva samples containing $0.05 \mathrm{M} \mathrm{PB}$ ( $\mathrm{pH} 7.0)$, with corresponding plots of $\mathrm{I}_{\mathrm{pa}} \mathrm{vs}$. $\left[\mathrm{H}_{2} \mathrm{~S}\right]$ for $(\mathbf{b})$ pond water, (d) urine, and (f) saliva samples.

Table 2. Detection of $\mathrm{H}_{2} \mathrm{~S}$ in pond water, urine, and saliva samples with the PtNi-modified electrode.

\begin{tabular}{ccccc}
\hline Samples & Added $(\mu \mathbf{M})$ & Found $(\mu \mathbf{M})$ & Recovery $(\%)$ & $*$ \\
\hline \multirow{2}{*}{ Pond water } & 0 & 0 & - & \multirow{2}{*}{3.39} \\
\cline { 2 - 4 } & 10 & 9.24 & 92.4 \\
\hline \multirow{2}{*}{ Human urine } & 0 & 0 & - & \multirow{2}{*}{4.2} \\
\cline { 2 - 4 } Saliva & 10 & 9.56 & 95.6 & \multirow{2}{*}{4.65} \\
\cline { 2 - 4 } & 0 & 0 & - &
\end{tabular}

* Related standard deviation (RSD) of three independent experiments.

\subsection{In Vitro Biological Sample Analysis}

Before the electrochemical detection of $\mathrm{H}_{2} \mathrm{~S}$ in live cells, the biocompatibility of $\mathrm{PtNi}$ was investigated. L929 and MDA-MB-231 cells were cultured with different concentrations 
of PtNi $\left(6.25,12.5,25,50\right.$, and $\left.100 \mu \mathrm{g} \mathrm{ml}^{-1}\right)$ and an MTT assay was performed to evaluate cell viability. Cell survival was inhibited in a concentration-dependent manner. The L929 and MDA-MB-231 cells showed more than $90 \%$ viability at $100 \mu \mathrm{g} \mathrm{ml}^{-1}$ (Figure 9a), indicating good biocompatibility of the as-prepared material. Therefore, PtNi could be useful for in vitro and in vivo analyses. Figure 9b,c shows the microscopic images of L929 and MDA-MB-231 cells cultured with PtNi alloy nanoparticles. The cells were healthy and proliferated well after $24 \mathrm{~h}$ of incubation with $\mathrm{PtNi}\left(10 \mu \mathrm{g} \mathrm{ml}^{-1}\right)$.
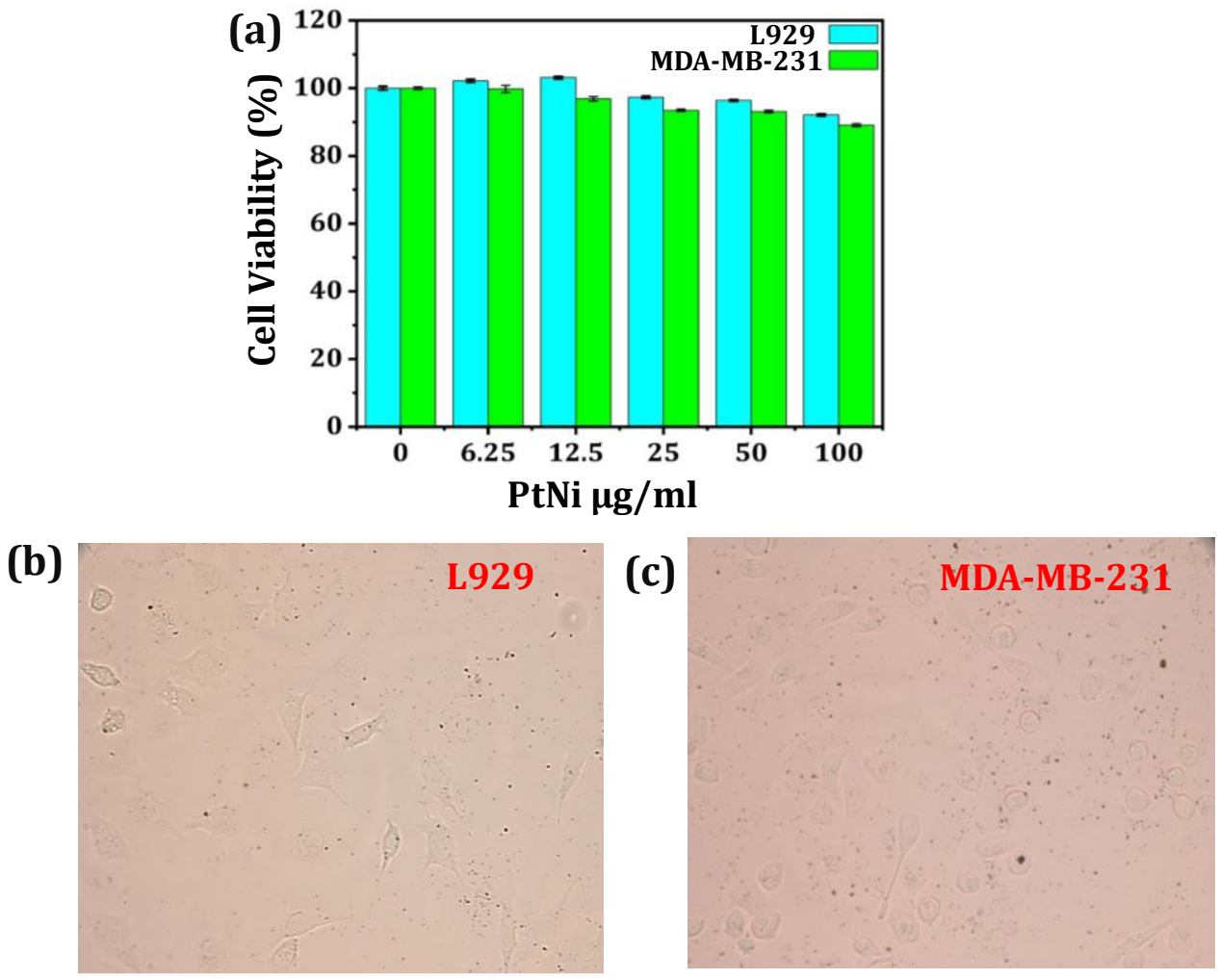

Figure 9. (a) Cell viability of L929 and MDA-MB-231 cells, microscopic images of (b) L929 and (c) MDA-MB-231 cells.

Amperometric analysis was performed to detect $\mathrm{H}_{2} \mathrm{~S}$ released from L929 and MDAMB-231 cells. VEGF was used as a stimulator for $\mathrm{H}_{2} \mathrm{~S}$ release from live cells. The L929 and MDA-MB-231 cells were cultured separately and tested using the amperometric technique in $0.05 \mathrm{M}$ PB at the optimum potential of $0.49 \mathrm{~V}$. A control experiment was performed in PB (7.0) without L929 and MDA-MB-231 cells. The current response did not change in these cells when VEGF was added to the PB. However, the current response increased with consecutive additions of $\operatorname{VEGF}(0,10$, and $20 \mu \mathrm{M})$ into PB containing L929 cells and MDA-MB-231, as shown in Figure 10a,b, respectively. The corresponding current response of $\mathrm{H}_{2} \mathrm{~S}$ released from L929 and MDA-MB-231 cells is shown in Figure 10c. The current response from MDA-MB-231 cells was 3.4-fold higher than that from L929 cells, confirming that cancer cells produce a higher concentration of $\mathrm{H}_{2} \mathrm{~S}$ than normal cells. These results suggest that PtNi could be a potential candidate for monitoring $\mathrm{H}_{2} \mathrm{~S}$ in live cells. The amperometry detection time for $\mathrm{H}_{2} \mathrm{~S}$ released from cancer cells was presented in Figure 10d. As depicted in Figure $10 \mathrm{~d}$, the $\mathrm{I}_{\mathrm{pa}}$ increased quickly with the successive additions of VEGF into PB-containing cells and reached a steady-state current within $3.3 \mathrm{~s}$ after the addition of VEGF. This result demonstrates the quick adsorption of $\mathrm{H}_{2} \mathrm{~S}$ molecules on the PtNi electrode surface. 

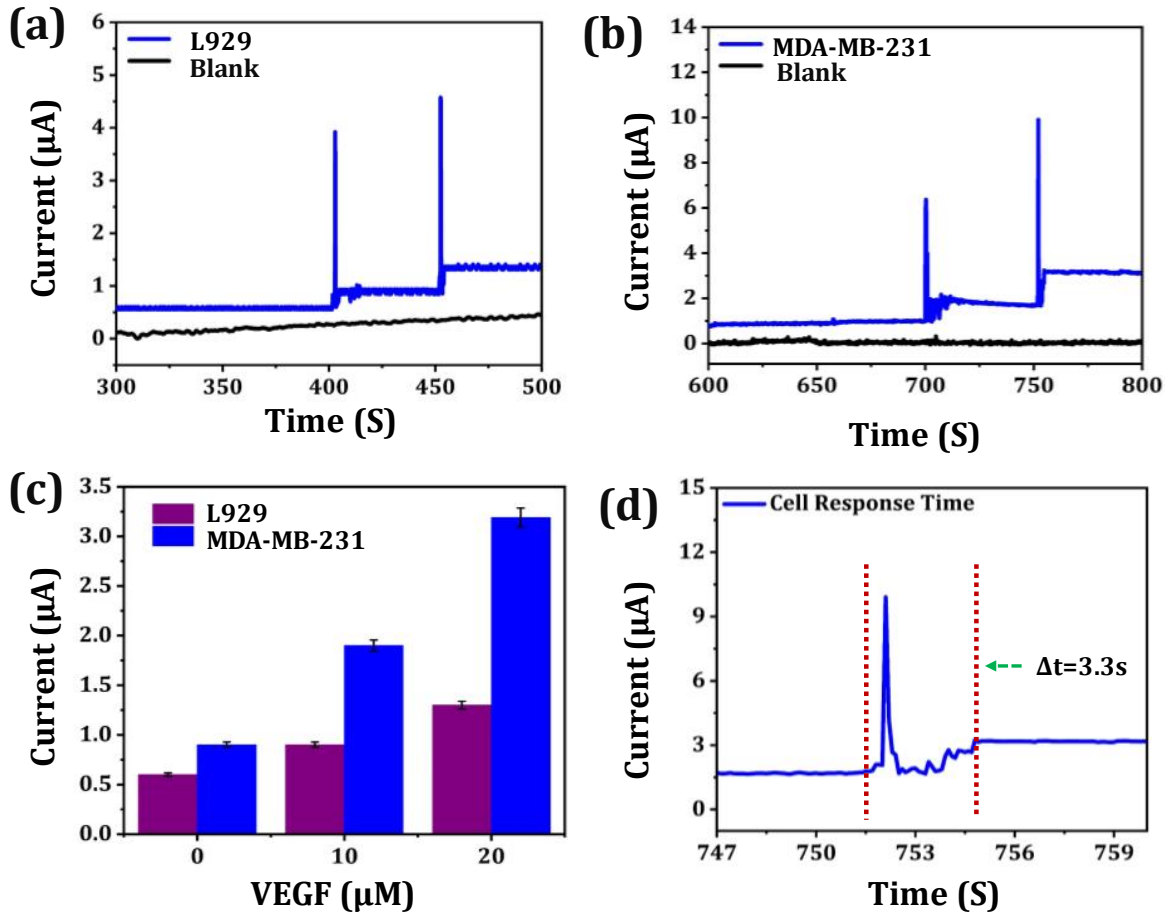

Figure 10. (a) Amperometric responses of PtNi to consecutive additions of VEGF $(0,10$, and $20 \mu \mathrm{M})$ without L929 and with L929 cells, (b) amperometric responses of PtNi-modified electrode to consecutive additions of VEGF stimulator $(0,10$, and $20 \mu \mathrm{M})$ without MDA-MB-231 and with MDA-MB-231 cells in $0.05 \mathrm{M} \mathrm{PB}$ at $0.49 \mathrm{~V}$, (c) corresponding current response between L929 and MDA-MB-231 cells with various concentrations of VEGF, (d) amperometric response time for $\mathrm{H}_{2} \mathrm{~S}$ released from cancer cells.

\section{Conclusions}

Herein, PtNi alloy nanoparticles were successfully prepared using a hydrothermal method for the detection of $\mathrm{H}_{2} \mathrm{~S}$. The average diameter of 5-6 nm of PtNi NPs were scrutinized by TEM analysis. Additionally, EDX, XRD, and XPS observations confirmed the successful formation of PtNi alloys. The PtNi sensor showed outstanding catalytic performance toward hydrogen sulfide oxidation with an LOD of $0.004 \mu \mathrm{M}$, sensitivity of

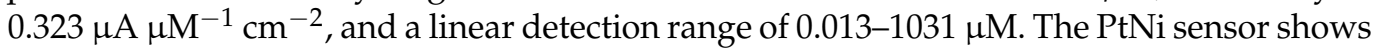
excellent selectivity towards $\mathrm{H}_{2} \mathrm{~S}$ oxidation and exhibits high anti-fouling by the interfering compounds. The repeatability, reproducibility, and long-term stability of the PtNi sensor were successfully demonstrated with RSD value of $3.37 \%, 3.89 \%$, and $4.82 \%$, respectively. The practical applicability of the PtNi sensor based on the quantification of $\mathrm{H}_{2} \mathrm{~S}$ in real samples such as pond water, human urine, and saliva samples was demonstrated with average recoveries of $92.4 \%, 95.6 \%$, and $98.8 \%$, respectively. Finally, we demonstrated that the PtNi sensor could be effectively applied for the detection of $\mathrm{H}_{2} \mathrm{~S}$ in live cells. Our results indicated that cancer cells (MDA-MB-231) released 3.4-fold higher levels of $\mathrm{H}_{2} \mathrm{~S}$ than normal cells (L929). Hence, the reported method has high potential for biomedical research related to $\mathrm{H}_{2} \mathrm{~S}$ production. 


\begin{abstract}
Author Contributions: Conceptualization, A.K.P., U.D., X.L. and R.-J.C.; methodology, A.K.P., M.K., R.S. and R.-J.C.; validation, A.K.P., M.K. and R.S.; formal analysis, A.K.P., M.K., R.S. and R.-J.C.; investigation, A.K.P., M.K., R.S. and R.-J.C.; data curation, A.K.P., M.K. and R.S.; writing-original draft preparation, A.K.P., M.K. and R.S.; writing—review and editing, A.K.P., M.K., R.S., U.D., X.L. and R.-J.C.; visualization, A.K.P., M.K., R.S. and R.-J.C.; supervision, U.D., X.L. and R.-J.C.; project administration, R.-J.C.; funding acquisition, R.S., U.D., X.L. and R.-J.C. All authors have read and agreed to the published version of the manuscript.
\end{abstract}

Funding: The authors are grateful for the financial support by the Ministry of Science and Technology of Taiwan (MOST 106-2221-E-027-034; MOST 109-2222-E-027-004), and the National Taipei University of Technology-Shenzhen University Joint Research Program (NTUT-SZU-108-05 (2019005); NTUTSZU-109-02 (2020009); NTUT-SZU-110-09 (2021009)).

Institutional Review Board Statement: The study was conducted according to the guidelines of the Declaration of Helsinki, and approved by the Research Ethics Committee of National Taiwan University (NTU-REC No.: 202104EM014, 20 May 2021).

Informed Consent Statement: Informed consent was obtained from all subjects involved in the study.

Data Availability Statement: Not applicable.

Acknowledgments: Technical assistance from the Precision Analysis and Material Research Center of National Taipei University of Technology (Taipei Tech) is appreciated.

Conflicts of Interest: The authors declare no conflict of interest.

\title{
References
}

1. Brown, M.D.; Hall, J.R.; Schoenfisch, M.H. A direct and selective electrochemical hydrogen sulfide sensor. Anal. Chim. Acta 2019, 1045, 67-76. [CrossRef] [PubMed]

2. Manibalan, K.; Mani, V.; Chang, P.-C.; Huang, C.-H.; Huang, S.-T.; Marchlewicz, K.; Neethirajan, S. Electrochemical latent redox ratiometric probes for real-time tracking and quantification of endogenous hydrogen sulfide production in living cells. Biosens. Bioelectron. 2017, 96, 233-238. [CrossRef] [PubMed]

3. Hu, X.-B.; Liu, Y.-L.; Wang, W.-J.; Zhang, H.-W.; Qin, Y.; Guo, S.; Zhang, X.-W.; Fu, L.; Huang, W.-H. Biomimetic graphene-based 3D scaffold for long-term cell culture and real-time electrochemical monitoring. Anal. Chem. 2018, 90, 1136-1141. [CrossRef]

4. Hall, J.R.; Schoenfisch, M.H. Direct electrochemical sensing of hydrogen sulfide without sulfur poisoning. Anal. Chem. 2018, 90, 5194-5200. [CrossRef]

5. Xu, T.; Scafa, N.; Xu, L.-P.; Zhou, S.; Al-Ghanem, K.A.; Mahboob, S.; Fugetsu, B.; Zhang, X. Electrochemical hydrogen sulfide biosensors. Analyst 2016, 141, 1185-1195. [CrossRef] [PubMed]

6. Shang, H.; Xu, H.; Wang, C.; Chen, C.; Wang, C.; Jin, L.; Du, Y. A new ratiometric electrochemical sensor using electroactive $\mathrm{GO} / \mathrm{MB} / \mathrm{Ag}$ nanocomposites for H $2 \mathrm{~S}$ detection in biological samples. J. Nanoparticle Res. 2020, 22, 1-10. [CrossRef]

7. Marzouk, S.A.; Al-Marzouqi, M.H. Analyzer for continuous monitoring of H2S in gas streams based on a novel thermometric detection. Sens. Actuators B Chem. 2012, 162, 377-383. [CrossRef]

8. Gu, W.; Zheng, W.; Liu, H.; Zhao, Y. Electroactive $\mathrm{Cu} 2 \mathrm{O}$ nanocubes engineered electrochemical sensor for H2S detection. Anal. chim. Acta 2021, 1150, 338216. [CrossRef]

9. Ibrahim, H.; Serag, A.; Farag, M.A. Emerging analytical tools for the detection of the third gasotransmitter H2S, a comprehensive review. J. Adv. Res. 2021, 27, 137-153. [CrossRef]

10. Bitziou, E.; Joseph, M.B.; Read, T.L.; Palmer, N.; Mollart, T.; Newton, M.E.; Macpherson, J.V. In situ optimization of pH for parts-per-billion electrochemical detection of dissolved hydrogen sulfide using boron doped diamond flow electrodes. Anal. Chem. 2014, 86, 10834-10840. [CrossRef]

11. Kaushik, R.; Ghosh, A.; Jose, D.A. Recent progress in hydrogen sulphide (H2S) sensors by metal displacement approach. Coord Chem. Rev. 2017, 347, 141-157. [CrossRef]

12. Rahman, N.S.A.; Greish, Y.E.; Mahmoud, S.T.; Qamhieh, N.N.; El-Maghraby, H.F.; Zeze, D. Fabrication and characterization of cellulose acetate-based nanofibers and nanofilms for H2S gas sensing application. Carbohydr. Polym. 2021, 258, 117643. [CrossRef] [PubMed]

13. Asif, M.; Aziz, A.; Ashraf, G.; Wang, Z.; Wang, J.; Azeem, M.; Chen, X.; Xiao, F.; Liu, H. Facet-inspired core-shell gold nanoislands on metal oxide octadecahedral heterostructures: High sensing performance toward sulfide in biotic fluids. ACS Appl. Mater. Interfaces 2018, 10, 36675-36685. [CrossRef] [PubMed]

14. Huang, Q.; Li, W.; Wu, T.; Ma, X.; Jiang, K.; Jin, X. Monoethanolamine-enabled electrochemical detection of H2S in a hydroxylfunctionalized ionic liquid. Electrochem. Commun. 2018, 88, 93-96. [CrossRef] 
15. Dionigi, F.; Weber, C.C.; Primbs, M.; Gocyla, M.; Bonastre, A.M.; Spori, C.; Schmies, H.; Hornberger, E.; Kuhl, S.; Drnec, J. Controlling near-surface Ni composition in octahedral $\mathrm{PtNi}(\mathrm{Mo})$ nanoparticles by Mo doping for a highly active oxygen reduction reaction catalyst. Nano Lett. 2019, 19, 6876-6885. [CrossRef]

16. Kumeda, T.; Otsuka, N.; Tajiri, H.; Sakata, O.; Hoshi, N.; Nakamura, M. Interfacial structure of PtNi surface alloy on Pt (111) electrode for oxygen reduction reaction. ACS Omega 2017, 2, 1858-1863. [CrossRef]

17. Li, W.; Zou, S. PtNi Nanoparticles Encapsulated in Few Carbon Layers as High-Performance Catalysts for Oxygen Reduction Reaction. ACS Appl. Energy Mater. 2019, 2, 2769-2778. [CrossRef]

18. Fan, C.; Wang, G.; Zou, L.; Fang, J.; Zou, Z.; Yang, H. Composition-and shape-controlled synthesis of the PtNi alloy nanotubes with enhanced activity and durability toward oxygen reduction reaction. J. Power Sources 2019, 429, 1-8. [CrossRef]

19. Yang, P.; Yuan, X.; Hu, H.; Liu, Y.; Zheng, H.; Yang, D.; Chen, L.; Cao, M.; Xu, Y.; Min, Y. Solvothermal synthesis of alloyed PtNi colloidal nanocrystal clusters (CNCs) with enhanced catalytic activity for methanol oxidation. Adv. Funct. Mater. 2018, 28, 1704774. [CrossRef]

20. Zhang, M.; Xiao, X.; Wu, Y.; An, Y.; Xu, L.; Wan, C. Hydrogen Production from Ammonia Borane over PtNi Alloy Nanoparticles Immobilized on Graphite Carbon Nitride. Catalysts 2019, 9, 1009. [CrossRef]

21. Lin, L.; Yuan, M.; Sun, Z.; Li, H.; Nan, C.; Sun, G.; Ma, S. The in situ growth of ultrathin Fcc-NiPt nanocrystals on graphene for methanol and formic acid oxidation. Dalton Trans. 2018, 47, 15131-15140. [CrossRef] [PubMed]

22. Guan, H.; Zhang, J.; Liu, Y.; Zhao, Y.; Zhang, B. Rapid quantitative determination of hydrogen peroxide using an electrochemical sensor based on PtNi alloy/CeO2 plates embedded in N-doped carbon nanofibers. Electrochim. Acta 2019, 295, 997-1005. [CrossRef]

23. Asif, M.; Aziz, A.; Wang, Z.; Ashraf, G.; Wang, J.; Luo, H.; Chen, X.; Xiao, F.; Liu, H. Hierarchical CNTs@ CuMn layered double hydroxide nanohybrid with enhanced electrochemical performance in H2S detection from live cells. Anal. Chem. 2019, 91, 3912-3920. [CrossRef] [PubMed]

24. Li, C.; Zhang, D.; Wang, J.; Hu, P.; Jiang, Z. Magnetic MoS2 on multiwalled carbon nanotubes for sulfide sensing. Anal. Chim. Acta 2017, 975, 61-69. [CrossRef] [PubMed]

25. Liu, Z.; Ma, H.; Sun, H.; Gao, R.; Liu, H.; Wang, X.; Xu, P.; Xun, L. Nanoporous gold-based microbial biosensor for direct determination of sulfide. Biosens. Bioelectron. 2017, 98, 29-35. [CrossRef]

26. Liu, X.; He, L.; Li, P.; Li, X.; Zhang, P. A Direct Electrochemical H2S Sensor Based on Ti3C2Tx MXene. ChemElectroChem 2021, 8, 3658-3665. [CrossRef] 